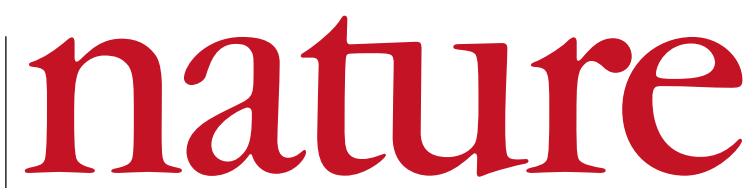

5 June 2003 Volume 423 Issue no 6940

\title{
Biodefence takes its toll
}

It is ironic, constitutionally questionable and misguided that in pursuit of vaccines against biowarfare agents, the Bush administration has attacked the very biomedical research budgets that have helped to make such defence possible.

$\mathrm{S}$ ince his appointment as US secretary of health and human services, Tommy Thompson has tried to tighten his department's grip over the National Institutes of Health (NIH) in myriad ways. Some may seem petty - after all, where is the harm in asking every NIH communication to carry his department's logo? But the Bush administration's latest command to the NIH is deadly serious. It is a prime example of how centralized control could undercut the NIH's mission of protecting the health of the United States and the world.

It all started a month ago, when the White House budget office told the National Institute of Allergy and Infectious Diseases (NIAID) to spend $\$ 233$ million on purchasing a new anthrax vaccine. The administration first asked for the money in its annual budget request to Congress last year, but researchers and their advocates convinced Congress that the NIAID should not spend research dollars buying vaccines. The administration's request was denied, and Congress redistributed the money among the other NIH institutes, without specifying who would pay for the vaccine.

Now the administration has stipulated that the anthrax vaccine money must come out of the NIAID's budget - a questionable move, as Congress is supposed to have the final say over federal spending. And because the administration has demanded that the money does not come from biodefence programmes, grants in such areas as basic immunology, infectious diseases and AIDS-vaccine research are being slashed or frozen. The NIH's congressional allies have tried to intervene on its behalf, and the White House is still talking to both Congress and the NIH. But the decision does not seem likely to be reversed.

The Bush administration does not need to be reminded of the crucial importance of the worldwide fight against AIDS. On 27 May, President George W. Bush signed a law authorizing Congress to spend
$\$ 15$ billion over five years on international AIDS-relief projects. President Bush himself proposed the measure, and his administration's support helped the AIDS bill move through Congress in just four months - practically the speed of light for Washington. But it makes no sense to enact such measures while crippling the researchers who are looking for the drugs and vaccines that make such programmes possible. And while AIDS research may seem unrelated to bioterrorism, the vast majority of antiviral drugs on the market were developed as countermeasures against HIV.

The latest row over the anthrax vaccine may not seem to be closely linked to the debate about the AIDS bill. But both can be seen as cases of political manoeuvring cloaked as protection of public health. Some have criticized the AIDS bill because it requires spending on religious programmes and abstinence, which will prevent it from funding some of the key groups fighting the epidemic in developing countries. Furthermore, there is doubt over whether President Bush will ask Congress to spend the money he asked for in his bill, or whether the authorizing measure is just an empty promise. Developing a new anthrax vaccine is a worthy goal. But gutting the basic research that has yielded the best defences against anthrax and other diseases is a poor way of achieving it. In both cases, the administration is giving the impression that it cares more about its public image than it does about tackling serious health problems.

The fight to control the NIH is more than just bureaucratic squabbling. It reflects an acute concern that central command will endanger the public health that the administration should protect, and the biomedical research that is necessary for that protection. If the Bush administration's main commitment to improving the US public-health system is to double the NIH's budget, the money should be used to strengthen — not debilitate — the agency and the researchers that are best placed to help.

\section{A meeting for Europe's scientists and publics}

\section{Scientific organizations should support the Euroscience Open Forum in 2004.}

$\mathrm{M}$ ost Nature readers will be aware of the annual meeting of the American Association for the Advancement of Science. It gives researchers the chance to describe their science to a diverse, non-specialized audience, offers forums for debates about issues relating to science, and provides an annual circus for hundreds of journalists from all over the globe.

In Europe, science-related issues are often more politically sensitive than in the United States, the public is fascinated by or critical of research, and there is an array of scientifically engaged media. Europe deserves such a meeting too, even if no one would expect it, in its early days, to achieve the scale and global media impact of its US equivalent.

This is why Nature is supporting the first Euroscience Open Forum (ESOF2004), to be held in Stockholm on 25-28 August next year (see www.esof2004.org). Stockholm's conference facilities are fully worthy of such a meeting, and sponsorship by several bodies has allowed an organizational framework to be established.
Despite the enthusiasm of its originators, the forum was not set up to pursue some European ideal. What matters is that the various themes of the meeting that are currently planned — ageing, the mind and behaviour, evolution, global change and more - are full of interesting content, and that scientists, stakeholders in science and the broader public can come together to discuss important issues, or simply to hear about hot science. Nature expects to support at least one such gathering at ESOF2004, and several significant European organizations are committed, or are about to commit, to partnership with the event as a whole.

Such an embryonic organization, as determined and self-motivated as it is, can benefit greatly from the support of the European Commission but must remain independent. It seems to be achieving this balance. Many laboratories and agencies are still considering their possible contributions to the event. Now is the right time for them to commit to this new conjunction of science and citizens. 